\author{
Case Study \\ www.ijrap.net (ISSN:2229-3566)
}

\title{
THE EFFECTIVENESS OF PRABHANJANA VIMARDANA TAILA AS PANA AND PICHU IN THE MANAGEMENT OF OSTEOARTHRITIS KNEE (JANU SANDHIGATA VATA): A CASE STUDY
}

\author{
Neetha Abraham *1, Miharjan. K. ${ }^{2}$, Lekshmi R. ${ }^{3}$, Arun Pratap ${ }^{4}$ \\ ${ }^{1}$ PG Scholar, Department of Kayachikitsa, Pankajakasturi Ayurveda Medical College and PG Centre, \\ Kattakkada, Thiruvananthapuram, India \\ ${ }^{2}$ Professor and Head, Department of Kayachikitsa, Pankajakasturi Ayurveda Medical College and PG Centre, \\ Kattakkada, Thiruvananthapuram, India \\ ${ }^{3}$ Assistant Professor, Department of Kayachikitsa, Pankajakasturi Ayurveda Medical College and PG Centre, \\ Kattakkada, Thiruvananthapuram, India \\ ${ }^{4}$ Associate Professor, Department of Kayachikitsa, Pankajakasturi Ayurveda Medical College and PG Centre, \\ Kattakkada, Thiruvananthapuram, India
}

Received on: 27/02/20 Accepted on: 25/04/20

\author{
*Corresponding author \\ E-mail: sisterneetharose@gmail.com
}

DOI: $10.7897 / 2277-4343.110352$

\begin{abstract}
Osteoarthritis (OA) is the most common form of arthritis. The knee is the most common joint affected in Osteoarthritis. The aim of this is to study the effectiveness of Prabhanjana Vimardana Taila as Pana and Janu Pichu in management of Osteoarthritis knee (Janu Sandhigata Vata). A 60 year old female patient came to our OPD with features of pain and swelling in right knee joint since 6 months with X-ray reports which showed Grade 2 degenerative changes. The patient was advised to take Prabhanjana Vimardana Taila as Pana (15 ml) at bed time with Mudga Yusha as Anupana and as Janu Pichu (1 hour daily) for 30 days. Assessment was done with Kellgren Lawrence scale, Goniometer, Measuring tape and WOMAC Score on the 0th day, 30th and 60th day of the study. The result is Womac Score - Before - 47, after - 15, Follow-up - 10. Goniometer reading (In degrees) Right Knee: flexion- Before - 110, after - 130, Follow up - 130. Left Knee: Flexion-Before After and Follow Up -130 Extension - Right and Left Knee: Before, After and Follow-up =0. Swelling Right Knee (In cm): Before - 34, after and follow up - 33. Swelling Left Knee (In cm): Before-33, after and Follow up - 32. In Osteoarthritis Knee (Janu sandhigatavata), where vitiated Vata gets localised in Sandhi produces Shotha, Vata Poorna Druti Sparsha and Prasarana Akunchana Vedana. Most of the drugs mentioned in Prabhanjana Vimardana Taila possess qualities such as Vata Kapha Samana, Ushna Veerya and Katu Vipaka which act as Sothahara, Vedana Sthapana, Balya and Rasayana. Remarkable changes were observed in subjective and objective parameters at the end of the treatment. Thus Prabhanjana Vimardana Taila found to be effective in the management of Osteoarthritis knee.
\end{abstract}

Keywords: Osteoarthritis, Prabhanjana Vimardana Taila, Janu Sandhigata Vata

\section{INTRODUCTION}

Osteoarthritis of the knee joint is a degenerative, non inflammatory joint disease. Its high prevalence especially in the old age is a leading cause for disability in the elderly. Obesity is a major risk factor which is a cause for increase in prevalence of the occurrence of Osteoarthritis. In the United States, Osteoarthritis prevalence will increase by $66-100 \%$ by $2020^{1}$. The overall prevalence of knee Osteoarthritis was found to be $28.7 \%$ in India ${ }^{2}$. The prevalence of Osteoarthritis increases with age, and with an aging population, the effect of this disease will represent an ever increasing burden on health care. The knee is the most common joint affected in Osteoarthritis, with up to $40 \%$ of limb arthritis being located in the knee, compared to $30 \%$ in hands and $19 \%$ in hips. It has been estimated that $45 \%$ of all people develop knee Osteoarthritis. Osteoarthritis is uncommon in adults under age 40 and highly prevalent in those over age 60. Symptoms attributable to Osteoarthritis are more prevalent in women than men. Globally Knee Osteoarthritis is $4^{\text {th }}$ most significant cause of incapability in women and $8^{\text {th }}$ in men $^{3}$.

The knee is the most common joint affected in Osteoarthritis. Osteoarthritis mainly targets patello-femoral and medial tibiofemoral compartments of the knee. Most knee Osteoarthritis particularly in women, is bilateral and symmetrical. Trauma is a more important risk factor in men and may result in unilateral Osteoarthritis. Osteoarthritis Knee Pain is usually localised to the anterior or medial aspects of the knee and upper Tibia. Patellofemoral pain is usually worse going up and down stairs or inclines. Posterior knee pain suggests a complicating popliteal cyst ${ }^{4}$. Osteoarthritis is an enlightened disorder of cartilage degradation, synovial inflammation, osteophyte formation, thinning of joint space and sub chondral sclerosis. Osteoarthritis leads to pain, disability as well as difficulty in joints. Contemporary medical sciences aim to give symptomatic relief of pain by analgesics including NSAIDs or joint displacement in end stage situations. An effective management is needed to repair and strengthen the cartilage and prevent further degeneration ${ }^{5}$.

Osteoarthritis can be understood by the principles of Sandhigata Vata in Ayurveda. Acharya Charaka has described the disease Sandhigatavata in Vatavyadhi Prakarana, where vitiated Vata gets localised in Sandhi producing symptoms like swelling (Shotha) on the joints, which is palpable as an air filled bag (Vata Poorna Druti Sparsha); and pain on flexion and extension of the joints (Prasarana Akunchana Vedana) ${ }^{6}$. The treatment for Sandhigata Vata has been mentioned as Snehana, Dahakarma and Upanaha $^{7}$. Acharya Sushruta advises Snehana, Upanaha, Agni karma, Bandhana and Unmardana for the treatment of Sandhigata Vata ${ }^{8}$. Acharya Charaka gives common principles of treatment of 
Vatavyadhi which comprises of Snehana, Swedana, Basti, Mridu Sodhana $^{9}$ etc. Snehana Karma in the form of Abhyantara and Bahya Sneha are usually done in Sandhigata Vata ${ }^{10}$. Prabhanjana Vimardana Taila ${ }^{11}$ mentioned in Sahasrayoga is having therapeutic indication in Vatavyadhi. As Taila is having Vyavayi (spreads all over the body), Ushna (hot), Guru (heavy), Sneha (oiliness) and Sukshma (subtle) properties which are opposite to the properties of Vata, it helps in alleviating the aggravated Vata $^{12}$.

\section{MATERIAL AND METHODS}

\section{Place of Study}

Pankajakasturi Ayurveda Medical College and Post Graduate Centre Hospital, Killy, Kattakkada, Thiruvananthapuram, India

\section{Ethical Clearance}

Ethical clearance has been obtained from the Institutional Ethical Committee (PKAMC/A-1/127/18) constituted by Pankajakasturi Ayurveda Medical College and Post Graduate Centre, Kattakkada, Thiruvananthapuram. Before starting the treatment, informed consent was taken from the patient on a printed consent form.

\section{Personal history}

\section{Case presentation}

A 60 year old female patient, Homemaker, reported to Kayachikitsa OPD, Pankajakasturi Ayurveda Medical College and PG Centre Hospital, Kattakkada, Thiruvananthapuram, India on 11/6/2019 with OP No: 19/80954 with complaints of pain and swelling of right knee joint since 6 months.

\section{History of presenting complaint}

The patient was asymptomatic before 6 months. There after she gradually developed pain and swelling in right knee joint. The pain was severe while climbing stairs. She found difficulty in standing for longer duration and pain usually got worsened on evening hours. The pain got slight relief on rest. She had morning stiffness which lasts for 10 minutes and subsides by itself, once she starts the day-to-day activities. She took allopathic topical analgesics and got symptomatic relief, there after the symptoms reoccurred once she stopped the medication. Thus she came to our OPD for better management through Ayurveda.

History of past illness: Nil relevant

Treatment history: Nothing Significant

Table 1: Personal History

\begin{tabular}{|c|c|}
\hline Appetite: Good & Bladder: Normal \\
\hline Allergy: Not Detected & Diet: Taking mixed diet, katu (spicy) - lavana (salt) - ushna ahara priyatva \\
\hline Addiction: Nil & Sleep: Sound \\
\hline Bowel: Regular & Physical Exercise: Moderate Labour \\
\hline
\end{tabular}

\section{Systemic examination}

\section{Locomotor system}

\section{Knee joint}

Inspection

Swelling was noted in right knee joint, there were no redness, muscular wasting and deformity.
Palpation

Grade-2 tenderness and there was presence of crepitus on right knee joint.

\section{Range of movements}

Both flexion and extension are painful on right knee joint.

\section{Investigations}

$\mathrm{ESR}-20 \mathrm{~mm} / \mathrm{hr}$

X-ray of right knee joint (Kellgren Lawrence Scale ${ }^{13}$ ) - Grade 2

Table 2: Kellgren-Lawrence Scale

\begin{tabular}{|c|c|}
\hline Grade & Description \\
\hline 0 & No radiographic features of osteoarthritis. \\
\hline 1 & Possible joint space narrowing and osteophyte formation. \\
\hline 2 & Definite osteophyte formation with possible joint space narrowing. \\
\hline 3 & Multiple osteophytes, definite joint space narrowing, sclerosis and possible bony deformity. \\
\hline 4 & Large osteophytes, marked joint space narrowing, severe sclerosis and definite bony deformity. \\
\hline
\end{tabular}

\section{Assessment criteria}

Assessment of subject was done by using

1. WOMAC Score ${ }^{14}$.

2. Goniometer Examination Scales for Knee range of movements.

3. Swelling of each Knee joint measured with Measuring Tape.

\section{Course of treatment}

The patient was given $15 \mathrm{ml}$ Prabhanjana Vimardana Taila as Pana (internal administration) with Mudga Yusha ${ }^{15}$ as Anupana at bed time and as Janu Pichu (application of medicated oil soaked cotton pad over the knee) for 1 hour daily for a period of 30 days. Assessment was done on the $0^{\text {th }}$ day, $30^{\text {th }}$ and $60^{\text {th }}$ day of the treatment. The patient was encouraged for review once in 15 days for uninterrupted feedback. 


\section{RESULT}

Table 3: Observations

\begin{tabular}{|c|c|c|c|c|c|}
\hline \multicolumn{2}{|c|}{ Parameter } & Before Treatment & After Treatment & Follow-up \\
\hline \multicolumn{2}{|c|}{ Womac Score (max. score: 96) } & 47 & 15 & 10 \\
\hline \multirow{2}{*}{$\begin{array}{c}\text { Goniometer } \\
\text { reading } \\
\text { (In degrees) }\end{array}$} & $\begin{array}{c}\text { Right } \\
\text { Knee joint }\end{array}$ & Flexion & 110 & 130 & 130 \\
\cline { 2 - 6 } & $\begin{array}{c}\text { Left } \\
\text { Knee joint }\end{array}$ & Flexionsion & 0 & 0 & 0 \\
\cline { 2 - 6 } & Extension & 130 & 130 & 0 \\
\hline \multirow{2}{*}{$\begin{array}{c}\text { Measuring } \\
\text { Tape }\end{array}$} & $\begin{array}{c}\text { Swelling Right Knee } \\
\text { (In cm) }\end{array}$ & 34 & 33 & 33 \\
\cline { 2 - 5 } & \multicolumn{2}{|c|}{$\begin{array}{c}\text { Swelling Left Knee } \\
\text { (In cm) }\end{array}$} & 33 & 32 & 32 \\
\hline
\end{tabular}

Thus Prabhanjana Vimardana Taila was found effective in reducing pain and swelling and thus reducing Womac Score along with changes in joint measurements and range of movements of knee joint. The medicine also proved effective in reducing tenderness and crepitus of knee joint. Also patient felt noticeable change in morning stiffness.

\section{DISCUSSION}

The prevalence of knee Osteoarthritis is increasing day by day. Systemic factors affecting joint vulnerability are gender, mainly females; age related factors; genetic and metabolic diseases and less intake of nutritional diet. Local factors acting on joints are obesity, occupation, injurious physical activity such as sports etc. These are the leading causes of Osteoarthritis. The pathogenesis involves biochemical and biophysical changes that may develop in cartilage along with synovium, ligaments, joint capsule and sub chondral bone. Cartilage erosion initially shows surface fibrillation and irregularity. As disease progresses focal erosion happens. Later cartilage loss will happen in larger area of the joint surface and there by degenerative process may start within the cartilage resulting in osteoarthritic changes.

The knowledge of Sandhigata Vata can be applied to understand Osteoarthritis and Knee Osteoarthritis can be correlated with Janusandhigata Vata. Adoption of food and activities similar to the properties of Vata results in Vata Vruddhi; because of Vata Vruddhi Bhava (Vata aggravating factors) and generally in Vardhakya Avastha (old age). Vata increases in the body with simultaneous decrease in Kapha. Whenever Vata increases, it leads to the Vaishamya of Agni (deranged digestive fire). So Jataragni and Dhatwagni both get impaired in their functions leading to defective formation of Dhatu. More over Vishamagni also causes further Prakopa of Vayu (Vyana Vata, which is responsible for all Chesta of the body like Prasarana, Akunchana etc specifically attains Prakopa here). Concurrently the same pathology also leads to reduction in Kapha; when Kapha residing in the Sandhi, i.e. the Sleshaka Kapha responsible for the lubrication of the joints reduces, Sandhi Shaithilyata results. Prakupita Vyana Vata settles in the Sandhi where Sleshaka Kaphakshaya exists, leads to symptoms like Shopha, Prasarana Akunchanavedana, and Atopa etc. In Ayurveda, Samprapti Vighatanameva Chikitsa (breaking of pathogenesis is treatment). For breaking the Samprapti (pathogenesis) of Janu Sandhigata Vata, Ushna (hot), Kapha Vatahara, Deepana (appetizer), Pachana (carminative), Sothahara, Vedanasthapana, Balya and Rasayana Dravyas are essential. Hence Prabhanjana Vimardana Taila is selected here. Taila is considered to be best in Vata Vyadhi. Prabhanjana Vimardana Taila was given in form of Pana (Abhyantara sneha) and Pichu (Bahya sneha). Snehana (Internal and External) is the measure adopted to bring about Snigdhata in the body. The patient got considerable relief in both subjective and objective parameters at the end of the treatment. This may be because of the properties of the drugs used in the formulation.
Drugs like Bala, Sahachara, Shigru, Varuna, Arka, Eranda, Shatavari, Ashwagandha, Prasarini and Brihat Panchmoola are having Vata Kapha Samana, Sothahara, Vedana Sthapana, Balya and Rasayana properties. Amara Kashta, Ela, Shunthi, Chora, Satahwa, Chitraka are having Kapha-Vatahara, Deepana and Hriday properties. Rasna is Kapha Vata hara and Rasayana. Sindhuta is Tridosha hara and Digestive. Ksheera (cow's milk) is another ingredient in the formulation which has Madhur Rasa (sweet in taste), Madhur Vipaka (state of food/drug after digestion), is Snigdha (unctuous), Guru (heavy) and it is good for Ojas and helps for Dhatu Pushti. Dadhi (curd) present in the Taila has Snigdha (unctuous) Guna, Madhur Vipaka (sweet after digestion), and Deepana (appetizer), and Bala Vardhaka properties, is Vata hara (mitigates Vata) and Ruchipradam (bestows taste). Kanjika (sour liquid) present in the Taila has Amla rasa (sour in taste), Ushna (hot) Veerya, is Ruchya (enhances taste), Vata Kapha Samana, Pachana (carminative), Deepana (appetizer) and Koshta Shudhikaram Param (it act as excellent in purifying the alimentary tract). Thus Prabhanjana Vimardana Taila is said to have Ushna Veerya and possess qualities such as Vata Kapha Samana, Sothahara, Vedana Sthapana, Balya and Rasayana properties, especially Brihat Panchmoola present in the Taila act as Kapha Vata Samana, Ama Pachana and best Sothahara. Thus internal administration (Pana) of Prabhanjana Vimardana Taila acts as Vata Samana, Sothahara, Balya and Rasayana.

The same Taila used externally as Pichu on the affected knee helped in reducing inflammation. Pichu helps in increased absorption of Taila and reducing the symptoms. Systemic absorption of drugs after topical application depends primarily on the lipid solubility of drugs. Local application of a drug at the desired site increases the concentration of the drug reaching the particular site. Application of medicated oil soaked cotton pads (Pichu) over the affected knee for a certain time enhances absorption of the active principles and helps in reducing the pain and promote strength of the person, thus it prevents the further progression of the disease.

\section{CONCLUSION}

Hence the treatment with Prabhanjana Vimardana Taila has a significant role in the management of Osteoarthritis knee (Janu Sandhigata Vata).

\section{ACKNOWLEDGEMENT}

The authors sincerely acknowledge Padmasree Dr. J. Hareendran Nair, Chief Physician, Kayachikitsa-Unit 1, Pankajakasturi Ayurveda Medical College and PG Centre Hospital for his valuable guidance regarding this clinical study. 


\section{REFERENCES}

1. Longo, Fauci, Kasper, Hauser, Jameson, Loscalzo, et al. Osteoarthritis. Harrisons Principles of Internal Medicine. $19^{\text {th }}$ ed. New York, NY: The Mc. Graw-Hill Companies; 2012. p. 2226.

2. Junfeng Zhang, Meta-analysis of serum C-reactive protein and cartilage oligomeric matrix protein levels as biomarkers for clinical knee osteoarthritis. Zhang BMC Musculoskeletal Disorders 2018; 19: 22.

3. K.V. Krishna Das, Osteoarthritis. Text Book of Medicine. Volume 1.6 $6^{\text {th }}$ Ed Jaypee Brothers Medicine Publishers; 2017. p. 777.

4. Brain R. Walker, Nicki R. Colledge, Stuart H. Ralston, Ian D. Penman, Osteoarthritis. Davidson's principles and practises of medicine. 22nd Ed. Edinberg London New York, Church hill Living stone, Elsevier Science Limited; 2014. p. 10811086.

5. Chandra Shekhar Azad et al. Osteoarthritis in India, An Epidemiologic Aspect. International Journal of Recent Scientific Research, 2017; 8(10): 20918-20922.

6. Agnivesha. Revised by Charaka and Dridhabala. Charaka Samhita with Ayurveda dipika commentary of Chakrapanidatta, Chikitsa sthana $5^{\text {th }}$ Vol. $29^{\text {th }}$ chapter $37^{\text {th }}$ sloka, Reprint 2012. Chaukhambha Orientalia Varanasi; 2007. p. 30.

7. Vagbhata Ashtanga Hridaya. Annotated by Dr. Anna Moreswao Kunte with the Commentaries: Sarwanga Sundara of Arunadatta and Ayurveda Rasayana of Hemadri Chikitsa Sthana 21/22. Chaukhambha Sanskrit Sansthan Varanasi; 2015. p. 724.

8. Sushruta, Sushruta Samhita with Dalhana commentary Chikitsa sthana. 4th chapter. 8th shloka. $2^{\text {nd }}$ Ed. Chaukhambha Orientalia Varanasi. p. 57.

9. Agnivesha. Revised by Charaka and Dridhabala. Charaka Samhita with Ayurveda dipika commentary of
Chakrapanidatta, Chikitsa sthana 5th vol. 28/75-83. Reprint 2012. Chaukhambha Orientalia Varanasi; 2007. p. 43-45.

10. Vagbhata Ashtanga Hridaya. Annotated by Dr. Anna Moreswao Kunte with the Commentaries: Sarwanga Sundara of Arunadatta and Ayurveda Rasayana of Hemadri Sutra Sthana 16/14. Chaukhambha Sanskrit Sansthan Varanasi; 2015. p. 246.

11. Dr. K. Nishteswar and Dr. R. Vidyanath. Sahasrayoga. Taila Prakarana 3/7. Text with English Translations. Chaukhambha Orientalia Varanasi; 2014. p. 113.

12. Agnivesha. Revised by Charaka and Dridhabala. Charaka Samhita with Ayurveda dipika commentary of Chakrapanidatta, Chikitsa sthana $5^{\text {th }}$ vol. 28/181-182, Reprint 2012. Chaukhambha Orientalia Varanasi; 2007. p. 68.

13. Kellgren JH, Lawerence JS. Radiological assessment of Osteoarthritis. Ann Rheum Dis 1957; 16: 494-502. [Pubmed]. ncbi.nlm.nih.gov.

14. Bellamy N Buchanan WW, Goldsmith $\mathrm{CH}$, et al. Validation study of WOMAC: A health status instrument for measuring clinically important patient relevant outcomes to anti rheumatic drug therapy in patients with Osteoarthritis of hip or knee. J Rheumatol 1988; 15: 1833-1840.

15. Sharangadhara. Sharangadhara Samhita madhyama khandaKwatha kalpana, 2/167-169. ed translated by Prof. K. R. Shrikanta moorthy. Chaukhamba Orientalia, Varanasi; 2012. p. 76 .

\section{Cite this article as:}

Neetha Abraham et al. The effectiveness of Prabhanjana Vimardana taila as Pana and Pichu in the management of Osteoarthritis Knee (Janu Sandhigata Vata): A Case Study. Int. J. Res. Ayurveda Pharm. 2020;11(3):16-19 http://dx.doi.org/ $\underline{10.7897 / 2277-4343.110352}$

Source of support: Nil, Conflict of interest: None Declared

Disclaimer: IJRAP is solely owned by Moksha Publishing House - A non-profit publishing house, dedicated to publishing quality research, while every effort has been taken to verify the accuracy of the content published in our Journal. IJRAP cannot accept any responsibility or liability for the site content and articles published. The views expressed in articles by our contributing authors are not necessarily those of IJRAP editor or editorial board members. 